\title{
Adult Fanconi syndrome with monoclonal abnormality of immunoglobulin light chain
}

\author{
J. F. HARRISON AND J. D. BLAINEY \\ From the Department of Experimental Pathology, The University of Birmingham
}

SYNOPSIS Two adult cases of the Fanconi syndrome are described, in each of which there was abnormal urinary excretion of immunoglobulin $\kappa$-chain. The significance of this finding is discussed? in relation to the recognized association between multiple myeloma and the Fanconi syndrome.

The Fanconi syndrome was defined by McCune, Mason, and Clarke (1943) as intractable normoazotaemic, hypophosphataemic rickets with chronic acidosis and glycosuria. Fanconi (1936) had been first to suggest that these symptoms resulted from defective renal tubular re-absorption without equivalent defect of glomerular filtration. The syndrome includes generalized aminoaciduria and, in the adult form, osteomalacia instead of rickets (Stowers and Dent, 1947). Often no reason for the tubular defect can be found but certain causes and associated diseases are recognized, among them multiple myeloma (Mudge, 1958; Milne, 1963). This paper describes two adult cases in each of which urinary protein with the physicochemical and antigenic properties of Bence Jones protein was detected and its excretion observed over a considerable period of time. Although the classical clinical features of multiple myeloma were absent, the findings resembled those in the six published case reports of multiple myeloma with the Fanconi syndrome.

\section{CASE REPORTS}

CASE 1 R.S., a man, born on 16 November 1923, presented in May 1963 having experienced tiredness, thirst, frequency of micturition, paraesthesiae, and periodic muscular weakness for about a year. There were no abnormal physical signs. The salient biochemical features appear in Table I, with the results of radiology and marrow biopsy. The urine contained granular casts and its specific gravity did not exceed 1010 after water deprivation for 14 hours. From these findings a diagnosis of the Fanconi syndrome was made; although osteomalacia was not shown radiologically and bone biopsy was not performed, the low serum phosphorus and raised alkaline phosphatase were suggestive of bone disease. A blood count and E.S.R. were normal.

Renal biopsy (Fig. 1a) showed gross swelling of the tubular cells which were packed with droplets and con-을 tained occasional birefringent crystals. Several glomeruliwere completely hyalinized; there was marked peri- $\widetilde{C}$ glomerular fibrosis and heavy interstitial infiltration, mainly by lymphocytes.

The patient has bzen maintained on sodium bicarbonate, $35 \mathrm{mEq}$./day, and potassium gluconate, $25 \mathrm{mEq} . /$ day. $\vec{\varphi}$ Except for polyuria his symptoms have remained in remission and he has returned to work. He received cyclophosphamide, $100 \mathrm{mg} . / \mathrm{day}$, from November 1963 O

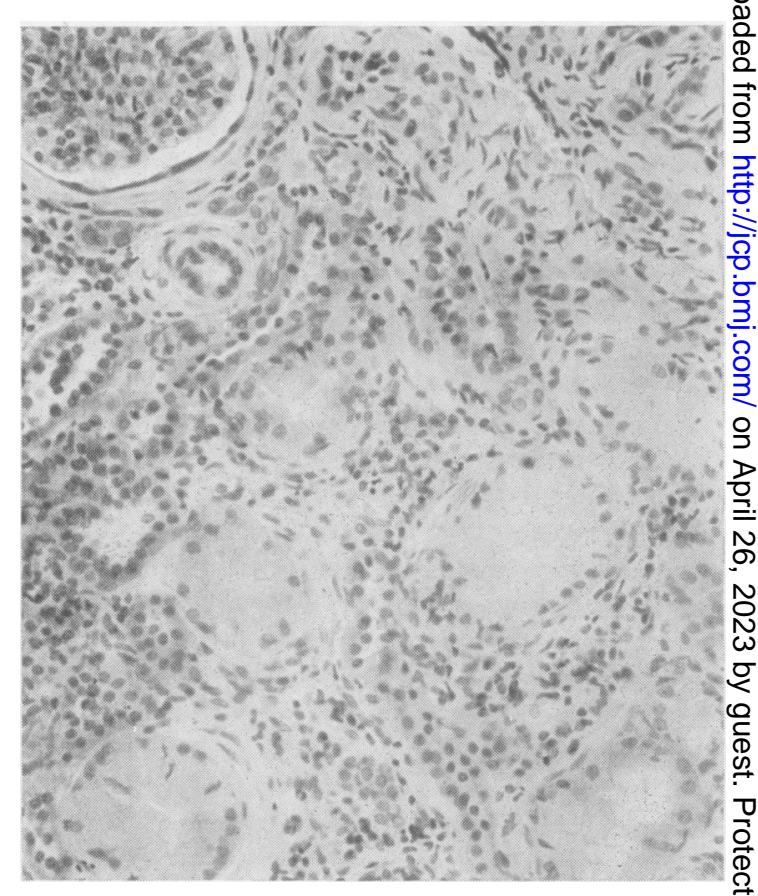

FIG. 1a. Renal biopsies from case 1. Haematoxylin and eosin $\times 150$. 


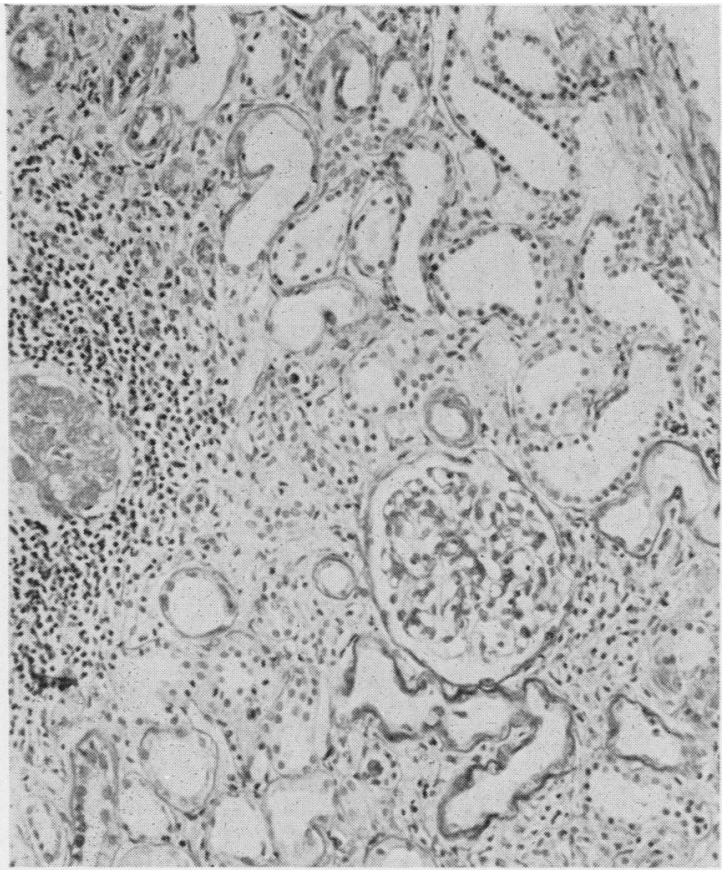

FIG. 1b. Renal biopsy from case 2. Periodic-acid Schiff $\times 150$.

to May 1954 without apparent effect. Serum creatinine, creatinine clearance, and serum and urine proteins have remained unchanged; he has not so far developed symptoms of osteomalacia. He was last seen in Feburary 1966.
CASE 2 H.W., a man born on 30 October 1919, had complained of tiredness, lassitude, and sharp, generalized muscular pains on sudden movements since 1961. Pain had developed in the tibiae, forearms, and ribs in 1963, and in 1964 he had noticed polyuria. For some years he had also had thinning of the skin on exposed areas, with a tendency there to bruise easily. Hospital investigations began in May 1965 when pain on movement of the shoulders, hips, and lumbar spine was noted, as well as 'senile' purpura on the backs of his hands. The main biochemical findings appear in Table I, with the results of radiology, bone biopsy, and marrow biopsy. From these data a diagnosis of the Fanconi syndrome was made. A blood count and E.S.R. were normal.

Renal biopsy (Fig. 1b) showed some normal proximal convoluted tubules but many tubules were lined with flattened cells; they could not be identified with certainty but were probably atrophic proximal tubules. Many glomeruli were completely hyalinized, and there were many small interstitial scars with heavy lymphocytic infiltration. The arterioles were normal for a man of his age.

The patient has been maintained on calciferol, $50,000 \mathrm{u} /$ day, potassium effervescent, $40 \mathrm{mEq} . /$ day, and calcium effervescent (Sandoz) $2.4 \mathrm{~g}$./day. In the ensuing nine months his symptoms, except for polyuria and bruising, have slowly regressed although he has not returned to work. Serum creatinine, creatinine clearance, and serum and urine proteins have remained unchanged; he was last seen in March 1966.

\section{PROTEIN STUDIES}

METHODS Total protein concentration was estimated by the biuret method (Hardwicke and Squire, 1955). Bence Jones protein was tested for by the sulphosalicylic acidheat test (Cook, 1951) and the $p \mathrm{H} 4.9$ heat test of Putnam,

TABLE I

REPRESENTATIVE BIOCHEM CAL AND OTHER FINDINGS IN EACH OF THE TWO REPORTED CASES

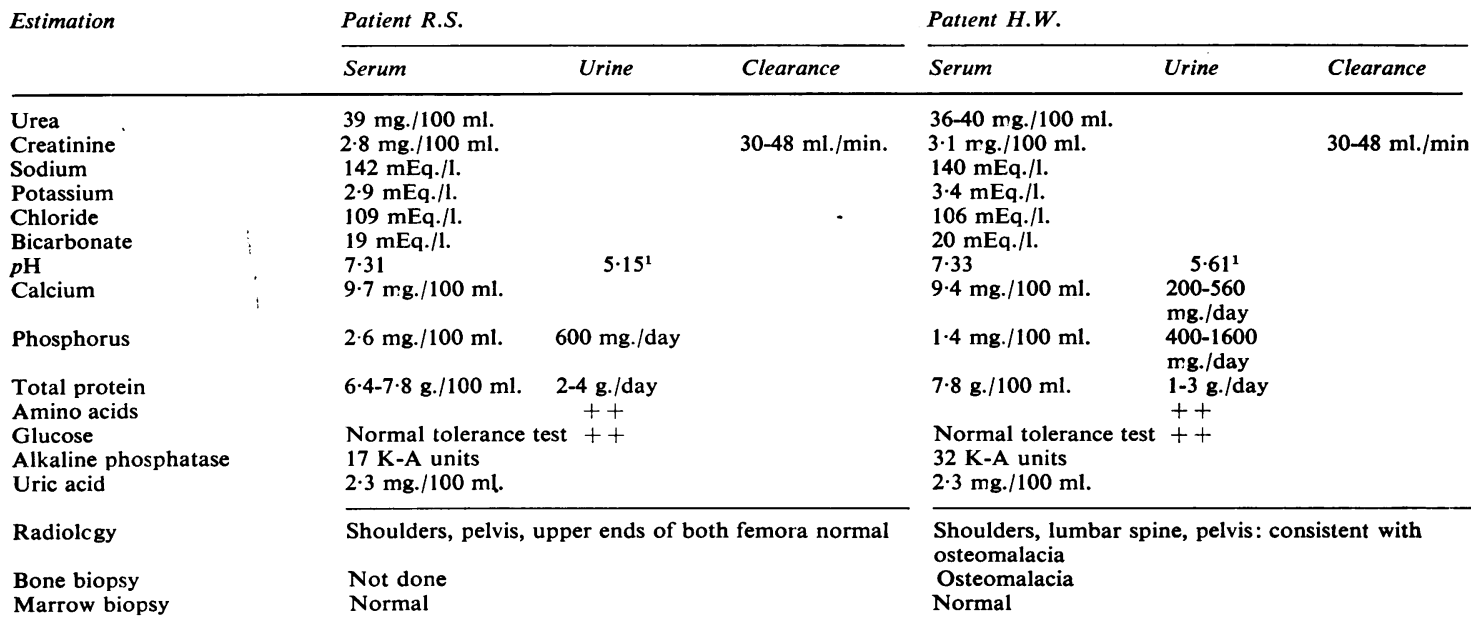

${ }^{\lrcorner}$Lowest value after ammonium chloride load $(0.1 \mathrm{~g} . / \mathrm{kg}$. body weight taken in 1 hour $)$ 
Easley, Lynn, Ritchie, and Phelps (1954). Quantitative paper electrophoresis was performed by the technique of Hardwicke (1954). Concentration of urine protein (by ultrafiltration), immuno-electrophoresis, gel filtration using columns of Sephadex G-100, and Ouchterlony analysis were all carried out as described by Harrison, Blainey, Hardwicke, Rowe, and Soothill (1966), and $\kappa$-chain protein (Nomenclature of Immunoglobulins, 1964) urine/serum ratios were estimated by the technique of Soothill (1962) using specific antisera and corresponding pairs of fractions from the Sephadex separations.

RESULTS In both cases the sulphosalicylic acid-heat test for urinary Bence Jones protein was positive, and the $p \mathrm{H} 4.9$ heat test gave precipitates at $56 \mathrm{C}$. which did not redissolve at $100^{\circ} \mathrm{C}$.

Paper electrophoresis (Fig. 2) of both patients' sera gave normal results. The urine of case 1 showed, among other electrophoretic components, a prominent $\gamma$ band characteristic of a myeloma globulin or Bence Jones protein and estimated to be $32 \%$ of the total protein. The concentrated urine protein showed the same components more prominently. The urine of case 2 showed an indefinite pattern reflecting its low protein concentration, but the concentrated urine protein displayed many electrophoretic components of which a fast $\gamma$ band was most prominent and constituted $33 \%$ of the total protein. This band was not unquestionably typical of a myeloma globulin or Bence Jones protein, but whereas in another case of the Fanconi syndrome (not reported in detail in this paper) all the other components found in case 2 were represented, the fast $\gamma$ band was not (Fig. 2) and in this respect its excretion seemed unlikely to have been a consequence of renal tubular disease.
Immunoelectrophoresis (Fig. 3) of the concentrated urine protein against antisera to the two immunoglobulin light chains showed in both cases an excess of $\kappa$-chain over $\lambda$-chain as compared with $\overline{0}$ normal serum and with urine protein from another case of the Fanconi syndrome. The $\kappa$-chain in $\frac{\bar{c}}{\sigma}$ case 2 was of faster mobility than that in case 1 ; both precipitation arcs were characteristic of type $K$ Bence Jones protein, of which an example from a case of classical multiple myeloma is shown in Fig. 3 . for comparison.

Gel filtration (Fig. 4) of the concentrated urine protein from both patients, with Ouchterlony analysis of the fractions, revealed no myeloma i globulins; most of the proteins, including the excess $\kappa$-chains, were smaller in molecular size than albumin. Similar examination of the sera confirmed the presence of small amounts of $\kappa$-chains of the $\mathrm{S}$ same molecular size, giving reactions of identity with the corresponding urinary proteins.

Estimation of $\kappa$-chain urine/serum ratios gave clearances $14 \%$ that of creatinine in case 1 , and $40 \% \stackrel{\text { ? }}{2}$ that of creatinine in case 2 . Since from the electro- $\vec{\theta}$ phoretic data the urine concentrations of the abnor- $\stackrel{\odot}{\circ}$ mal components were known, if these represented $\kappa$-chain concentrations then from the urine/serum ratios the serum $\kappa$-chain levels could be estimated; the figures were $0.02 \mathrm{~g} . / 100 \mathrm{ml}$. in case 1 and $0.004 \mathrm{~g} . / 100 \mathrm{ml}$. in case 2.

\section{DISCUSSION}

The two cases showed all the features of the adult Fanconi syndrome except that osteomalacia was not histologically proven in case 1 . Despite reduced

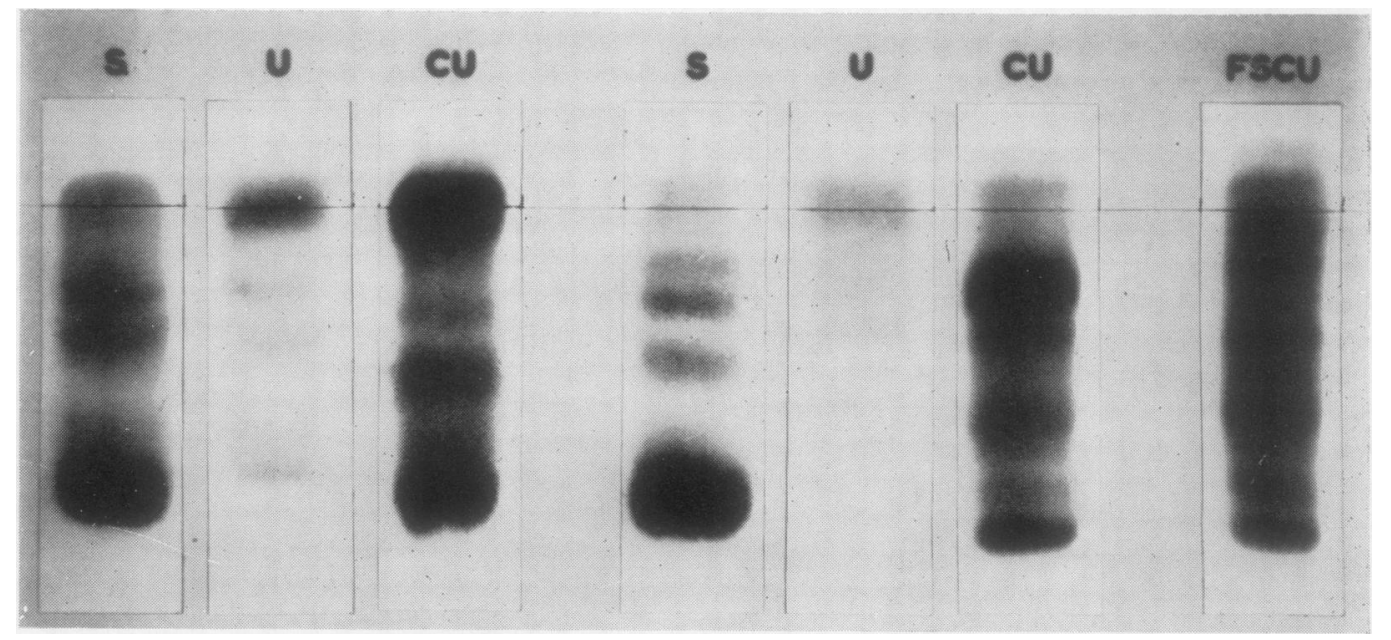

FIG. 2. Paper electrophoresis of serum $(S)$, urine $(U)$, and concentrated urine protein $(C U)$ from, on the left, case 1 , and $\stackrel{\square}{\varrho}$ on the right, case 2, with concentrated urine protein from another case of the Fanconi syndrome (FSCU) for comparison. 

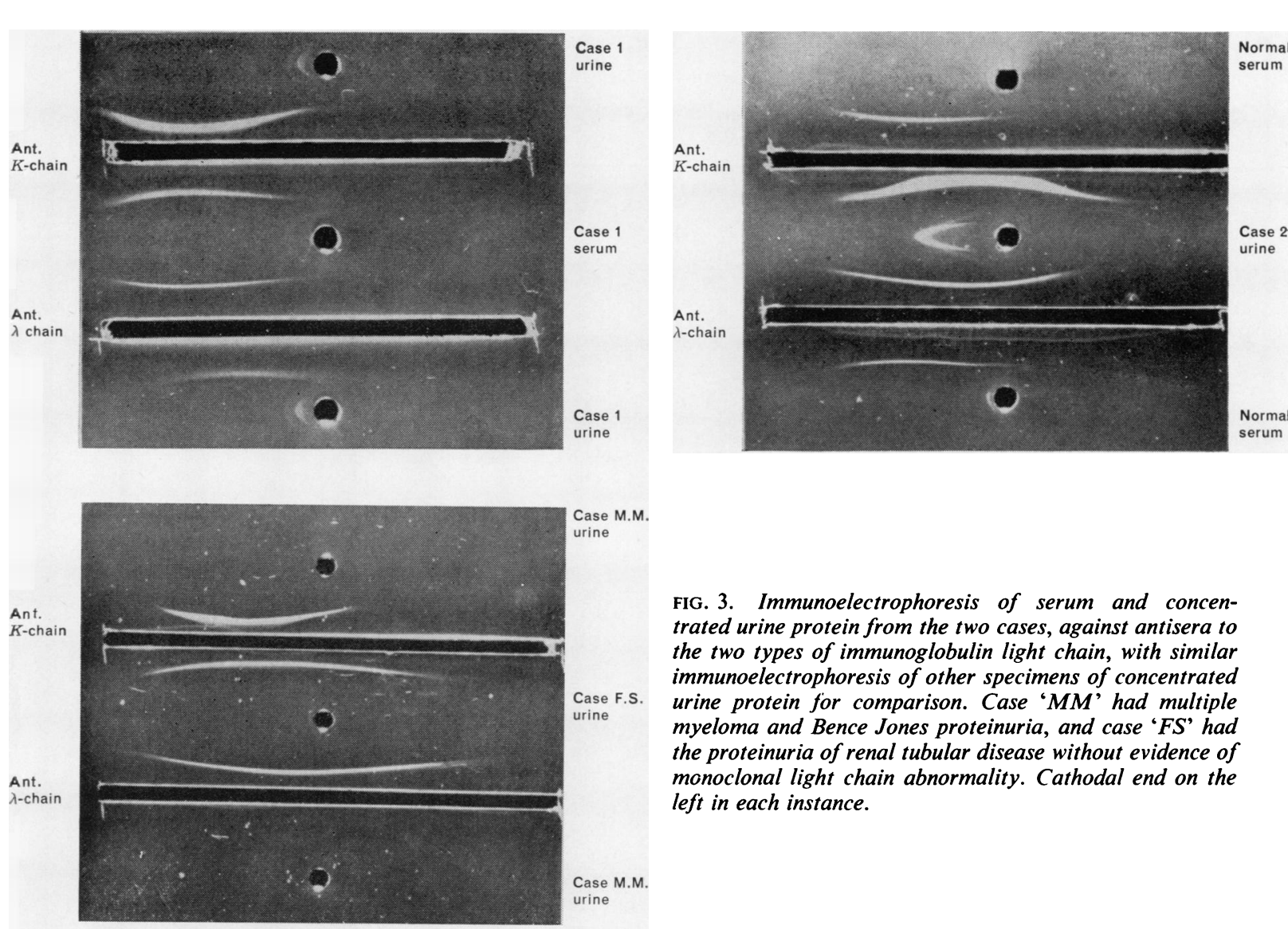

FIG. 3. Immunoelectrophoresis of serum and concentrated urine protein from the two cases, against antisera to the two types of immunoglobulin light chain, with similar immunoelectrophoresis of other specimens of concentrated urine protein for comparison. Case ' $M M$ ' had multiple myeloma and Bence Jones proteinuria, and case ' $F S$ ' had the proteinuria of renal tubular disease without evidence of monoclonal light chain abnormality. Cathodal end on the left in each instance.

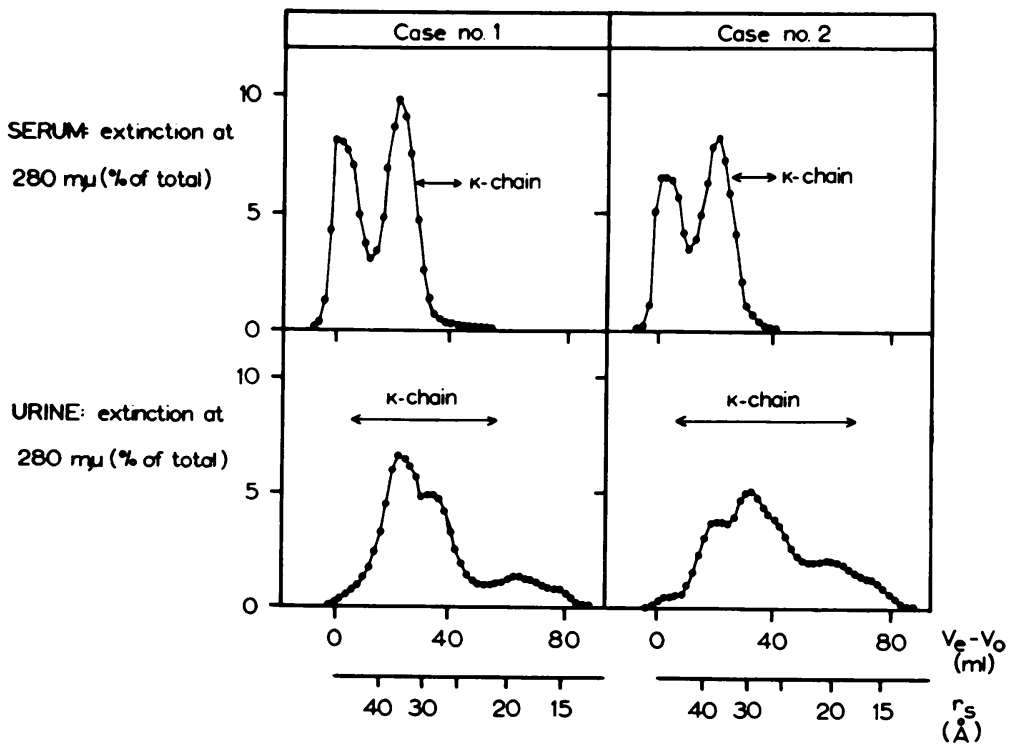

FIG. 4. Sephadex $G-100$ gel filtration elution patterns of serum and concentrated urine protein from the two cases. The distribution of $\kappa$-chain protein in each separation is indicated.

There are two abscissa scales: $V_{e}-V_{o}$ indicates elution volume in $m l .$, and $r_{s}$ indicates approximate molecular radius (EinsteinStokes radius) in Angstrom units. $A$ full description of the technique is given by Harrison et al. (1966). 
TABLE II

\begin{tabular}{|c|c|c|c|c|c|c|}
\hline \multirow[b]{2}{*}{ Author } & BLISHED CASES & \multirow{2}{*}{$\begin{array}{l}\text { OF THE FA } \\
\text { Onset to } \\
\text { Diagnosis (yr.) }\end{array}$} & ANCONI SYNDROME & \multicolumn{2}{|c|}{ WITH MULTIPLE MYELOMA } & \multirow[b]{2}{*}{$\begin{array}{l}\text { Serum } \\
\text { Phosphorus } \\
\text { (mg. } / 100 \mathrm{ml} \text {. }\end{array}$} \\
\hline & $\begin{array}{l}\text { Sex and Age at } \\
\text { Diagnosis }\end{array}$ & & $\begin{array}{l}\text { Onset to } \\
\text { Death }(y r .)\end{array}$ & $\begin{array}{l}\text { Clinical Evidence of } \\
\text { Multiple Myeloma }\end{array}$ & $\begin{array}{ll}\text { Evidence of } & S \\
\text { Glomerular Filtration } & P \\
\text { Rate } & (n\end{array}$ & \\
\hline Sirota and Hamerman (1954) & M 54 & $\begin{array}{l}\text { Fanconi } \\
\text { syndrome: } 3 \\
\text { Multiple } \\
\text { myeloma: } 7\end{array}$ & Alive at 9 & $\begin{array}{l}\text { Serum protein } \\
\text { Marrow: } 8-14 \% \text { plasma } \\
\text { cells }\end{array}$ & $\begin{array}{l}\text { BUN } 10-40 \mathrm{mg} \cdot / 100 \mathrm{ml} . \\
\text { Cin } 32 \% \text { of normal }\end{array}$ & 1.5 \\
\hline Dragsted and Hjörth (1956) & M 49 & $? 7$ & $? 9$ & $\begin{array}{l}\text { Marrow: } 84 \% \text { plasma } \\
\text { cells }\end{array}$ & $\begin{array}{l}\text { Blood urea } 20-50 \\
\mathrm{mg} . / 100 \mathrm{ml} .\end{array}$ & $2 \cdot 4$ \\
\hline Engle and Wallis (1957) & M 38 & 3 & 5 & $\begin{array}{l}\text { Marrow: } 34 \% \text { plasma cells } \\
\text { Radiograph: generalized } \\
\text { demineralization, later } \\
\text { typical myeloma }\end{array}$ & $\begin{array}{l}\text { BUN } 9 \mathrm{mg} . / 100 \mathrm{ml} . \\
\text { Urea clearance } \\
\text { normal }\end{array}$ & $2 \cdot 6$ \\
\hline Muntendam (1958) & F 54 & $\begin{array}{l}\text { Fanconi } \\
\text { syndrome: } 4 \\
\text { Multiple } \\
\text { myeloma: } 4\end{array}$ & Alive ?5 & $\begin{array}{l}\text { Marrow: excess plasma cells } \\
\text { Extramedullary myeloma } \\
\text { (biopsied) }\end{array}$ & $\begin{array}{l}\text { Blood urea } 40 \\
\mathrm{mg} . / 100 \mathrm{ml} . \\
\mathrm{Ccr} 48 \mathrm{ml} . / \mathrm{min} .\end{array}$ & $2 \cdot 1$ \\
\hline Short and Smith (1959) & M 65 & 1 & 14 & $\begin{array}{l}\text { Serum protein } \\
\text { Marrow: excess plasma cells } \\
\text { Radiograph: typical } \\
\text { myeloma }\end{array}$ & $\begin{array}{l}\text { Blood urea } 84-118 \\
\mathrm{mg} . / 100 \mathrm{ml} . \\
\text { Ccr } 9 \mathrm{ml} . / \mathrm{min} .\end{array}$ & $4 \cdot 2$ \\
\hline Costanza and Smoller (1963) & F 67 & 1 & $\mathbf{1}$ & $\begin{array}{l}\text { Serum protein } \\
\text { Marrow: excess plasma cells } \\
\text { Radiograph: tpyical } \\
\text { myeloma }\end{array}$ & $\begin{array}{l}\text { BUN } 62-105 \mathrm{mg} . / 100 \mathrm{ml} \\
\text { Cer } 9-12 \mathrm{ml} . / \mathrm{min} .\end{array}$ & $2 \cdot 9$ \\
\hline Dedmon et al. (1963) & M 51 & 3 & 4 & $\begin{array}{l}\text { Serum protein } \\
\text { Necropsy: myeloma cells } \\
\text { at rib fracture sites }\end{array}$ & $\begin{array}{l}\text { BUN } 27 \mathrm{mg} . / 100 \mathrm{ml} . \\
\text { Ccr } 55 \mathrm{ml} . / \mathrm{min} .\end{array}$ & $2 \cdot 5$ \\
\hline
\end{tabular}

creatinine clearances and renal biopsies showing hyalinized glomeruli, the biopsies suggested that tubular damage exceeded glomerular damage in each case. Possibly the swollen tubules in case 1 represented an earlier phase, and the flattened tubules in case 2 a later phase of the same disease process, but of this no certain evidence is available.

The conclusions from the protein studies may be summarized as follows. The urine in both cases contained, besides the abnormal $\gamma$ components, proteins which electrophoretically (Butler and Flynn, 1958) and on gel filtration (Harrison and Northam, 1966) were typical of the proteinuria of renal tubular disorders, especially the Fanconi syndrome. They may therefore be assumed to have been excreted as a consequence of renal tubular disease.

The abnormal $\gamma$ components on the other hand were electrophoretically suggestive of myeloma globulins or Bence Jones protein and untypical of the proteinuria of renal tubular disease. Although no myeloma globulins were detected both patients were excreting much more immunoglobulin $\kappa$-chain than $\lambda$-chain. The $\kappa$ chains' electrophoretic mobilities accorded with those of the respective abnormal bands on paper electrophoresis. Their molecular sizes and renal clearances were the same as those of Bence Jones proteins and since there is no evidence that the renal clearances of the $\kappa$ - and $\lambda$-chains are greatly different (Harrison et al., 1966) the urinary preponderance of the $\kappa$-chain must have represented a similar preponderance in the sera, although the serum $\kappa$-chain levels were too low for abnormal bands to appear on paper electrophoresis. (In case 2 this was confirmed by direct estimation of the serum levels of the $\kappa$ - and $\lambda$-chain by a haemagglutination inhibition technique; Burdon, personal communication).

All immunoglobulins, including light-chain proteins, in normal serum and urine and in proteinuria, whether due to glomerular or tubular disease, contain type $\mathrm{K}$ and type $\mathrm{L}$ components in not greatly dissimilar proportions (Fahey and Solomon, 1963; Stevenson, 1962; Takatsuki and Osserman, 1964; Harrison, 1966). In a given case of multiple myeloma or macroglobulinaemia on the other hand the abnormal proteins belong invariably either to type $K$ or type L (Mannik and Kunkel, 1962; Fahey and Solomon, 1963); this fact has been regarded as consistent with, and indicative of, the formation of the abnormal proteins by single clones of cells. The 
TABLE II

\begin{tabular}{|c|c|c|c|c|c|c|c|c|}
\hline \multirow{3}{*}{ Osteomalacia } & \multirow{3}{*}{$\begin{array}{l}\text { PUBLISHE } \\
\text { Aminoaciduria }\end{array}$} & D CASES & OF & THE FANC & DNI SYNDROME & WITH & TIPLE MYELOMA-continu & led \\
\hline & & \multirow[t]{2}{*}{ Glj'cosuria } & & \multirow{2}{*}{$\begin{array}{l}\text { Serum } \\
\text { Protein }\end{array}$} & \multirow[t]{2}{*}{ Urine Protein } & \multicolumn{3}{|c|}{ Renal Biopsy or Post-mortem Histology } \\
\hline & & & & & & Glomeruli & Tubules & Interstitium \\
\hline+ & + & + & & $\begin{array}{l}\text { Sharp band, } \\
\text { slow } \gamma\end{array}$ & $\begin{array}{l}\text { BJ negative at } \\
\text { 3yr.; positive at } \\
\text { 7yr. }\end{array}$ & - & - & 一 \\
\hline+ & + & + & & Low $\gamma$ & $\begin{array}{l}\text { Proteinuria pre- } \\
\text { sent: no other } \\
\text { comment }\end{array}$ & $\begin{array}{l}\text { Some } \\
\text { hyalinised }\end{array}$ & $\begin{array}{l}\text { Degeneration: deeply } \\
\text { stained casts }\end{array}$ & Fibrosis \\
\hline 一 & + & + & & Low $\gamma$ & $\begin{array}{l}10-20 \mathrm{~g} \cdot / \text { day } \\
\text { BJ positive } \\
\beta \text { band }\end{array}$ & $\begin{array}{l}\text { Some } \\
\text { sclerotic }\end{array}$ & $\begin{array}{l}\text { Dilated: vacuolated cells } \\
\text { with crystals, laminated } \\
\text { casts }\end{array}$ & $\begin{array}{l}\text { Round cell } \\
\text { infiltration, giant } \\
\text { cells }\end{array}$ \\
\hline+ & + & + & & normal & BJ positive & - & 一 & - \\
\hline- & + & + & & $\begin{array}{l}\text { Sharp band, } \\
\text { fast } \gamma\end{array}$ & $\begin{array}{l}\text { BJ positive } \\
\text { Fast } \gamma \text { band }\end{array}$ & Normal & $\begin{array}{l}\text { Widespread severe atrophy, } \\
\text { casts }\end{array}$ & $\begin{array}{l}\text { Fibrosis, round cell } \\
\text { infiltration, giant cells }\end{array}$ \\
\hline- & + & + & & $\begin{array}{l}\text { Sharp band, } \\
\gamma\end{array}$ & $\begin{array}{l}\text { BJ negative } \\
\gamma \text { band with } \\
\text { others }\end{array}$ & Normal & $\begin{array}{l}\text { Needle-like inclusion bodies, } \\
\text { casts }\end{array}$ & Giant cells \\
\hline+ & + & + & & $\begin{array}{l}\text { Sharp band, } \\
\gamma, 25 S\end{array}$ & $\begin{array}{l}\gamma \text { band with } \\
\text { others }\end{array}$ & & $\begin{array}{l}\text { Crystals in cells } \\
\text { (no other details) }\end{array}$ & Giant cells \\
\hline
\end{tabular}

BUN $=$ blood urea nitrogen. $\mathrm{C}_{\mathrm{in}}=$ inulin clearance $\mathrm{BJ}=$ = Bence Jones nitrogen

evidence therefore is that each of the present patients had monoclonal light-chain proteinaemia with consequent light-chain (Bence Jones) proteinuria.

Although neither patient displayed clinical features typical of multiple myeloma, it is known that constant serum levels of myeloma globulin may persist for many years without other evidence of disease. Often in such cases there is later transition to multiple myeloma (Osserman, 1958) but Waldenström (1944, 1964) has recognized a distinct condition in which no such transition occurs, and has used the term 'benign essential monoclonal hyperglobulinaemia' to describe it. The existence of an analagous 'benign essential Bence Jones proteinuria', of which the two present cases may be examples, seems plausible but has not until now been described.

The two patients' Fanconi syndrome may have been the result or the cause of the monoclonal protein abnormality, or may have been independent of it. In this connexion it is instructive to examine the features of the six reported cases of the adult Fanconi syndrome accompanying multiple myeloma, which are summarized in Table II. The Table includes a further case (Short and Smith, 1959) which the authors discuss in the context of the Fanconi syndrome and in which damage to the proximal convoluted tubules was anatomically demonstrated. Neither this case nor that of Costanza and Smoller (1963) strictly merit the description 'Fanconi syndrome' because they were azotaemic, normophosphataemic, and lacked evidence of osteomalacia. In the other five cases symptoms had preceded diagnosis by at least three years; only one patient had radiological evidence of multiple myeloma and this was terminal; in three no abnormal serum protein was demonstrated and in a fourth the abnormal serum protein behaved as a macroglobulin in the ultracentrifuge. Thus the complete Fanconi syndrome has never presented as a complication of radiologically classical multiple myeloma and has been consistently associated with a relatively benign course of the myeloproliferative disorder. Also, in all the cases in which it was looked for, Bence Jones protein was found. The two present cases therefore fit this general picture well, and to this extent it is reasonable to suppose that their renal lesions were secondary to their production of immunoglobulin light chains.

The situation contrasts with the frequent asso- 
ciation between classical multiple myeloma and azotaemic renal failure. In these circumstances the histological picture of renal damage is variable (Greenwald, Bronfin, and Auerbach, 1953; Ruffié, Bouissou, Fournié, Suc, and Putois, 1963): glomerular filtration is usually impaired at least as severely as tubular reabsorption (Armstrong, 1950; Goldman, Adams, and Luchsinger, 1952) and there is electron microscopic evidence of glomerular as well as tubular damage (Fisher, Perez-Stable, and Zawadski, 1964). The precise cause of renal damage in multiple myeloma is not understood but probably differs in different cases, and obstruction by protein casts and toxic damage to the tubule cells are two likely mechanisms. The two present cases, and the cases quoted above from the literature, suggest that possibly the Fanconi syndrome may arise from longcontinued damage to the tubules by some metabolite in relatively low dosage. The abnormal $\kappa$-chains (Bence Jones proteins) themselves may act in this way, but at present this remains unproved. The association between the Fanconi syndrome and Wilson's disease (Lavelle, 1964; Dent and Stowers, 1965) may represent a similar situation,

The question arises whether similar protein abnormalities in the adult Fanconi syndrome have previously passed undetected. Among 40 cases in the literature reviewed by the present authors several have given positive heat tests for Bence Jones protein but there are no descriptions of the methods used, and it is known for example that the sulphosalicylic acid-heat test may give a positive result for Bence Jones protein with the proteinuria of renal tubular disease (Butler and Flynn, 1958). Electrophoresis of the urine protein has been performed in some instances, but of the concentrated urine protein only rarely; the present cases illustrate the potential interest of this investigation, particularly if combined with immunoelectrophoresis against appropriate specific antisera. Further investigation of suitable cases along the present lines may lead to greater understanding of the causes of renal disease characterized by proximal tubular damage.

One of us (J. F. Harrison) has been in receipt of a grant from the United Birmingham Hospitals Endowment Research Fund. We are grateful to Dr. A. G. W. Whitfield for allowing us to study case 2.

\section{REFERENCES}

Armstrong, J. B. (1950). Amer. J. med. Sci., 219, 488.

Butler, E. A., and Flynn, F. V. (1958). Lancet, 2, 978.

Cook, I. (1951). J. med. Lab. Technol., 9, 179.

Costanza, D. J. and Smoller, M. (1963). Amer. J. Med. 34, 125.

Dedmon, R. E., West, J. H., and Schwartz, T. B. (1963). Med. Clin. N. Amer., 47, 191.

Dent, C. E., and Stowers, J. M. (1965). Brit. med. J., 1, 520.

Dragsted, P. J., and Hjörth, N. (1956). Dan. med. Bull., 3, 177.

Engle, R. L., Jr., and Wallis, L. A. (1957). Amer. J. Med., 22, 5.

Fahey, J. L., and Solomon, A. (1963). J. clin. Invest., 42, 811.

Fanconi, G. (1936). Dtsch. med. Wschr., 62, 1169.

Fisher, E. R., Perez-Stable, E. and Zawadski, Z. A. (1964). Lab. Invest., 13, 1561.

Goldman, R., Adams, W. S., and Luchsinger, E. B. (1952). J. Lab. clin. Med., 40, 519.

Greenwald, H. P., Bronfin, G. J., and Auerbach, O. (1953). Amer. J. Med., 15, 198.

Hardwicke, J. (1954). Biochem. J., 57, 166.

—-, and Squire, J. R. (1955). Clin. Sci., 14, 509.

Harrison, J. F. (1966). Unpublished observations.

- Blainey, J. D., Hardwicke, J., Rowe, D. S., and Soothill, J. F. (1966). Clin. Sci., 31, 95.

_- and Northam, B. E. (1966). Clin. chim. Acta, 14, 679.

Lavelle, M. I. (1964). Proc. roy. Soc. Med., 57, 592.

McCune, D. J., Mason, H. H., and Clarke, H. T. (1943). Amer. J. Dis. Child. 65, 81 .

Mannik, M., and Kunkel, H. G. (1962). J. exp. Med., 116, 859.

Milne, M. D. (1963). In Diseases of the Kidney, edited by M. B Strauss and L. G. Welt. Churchill, London.

Mudge, G. H. (1958). Amer. J. Med., 24, 758.

Muntendam, D. H. (1958). Ned. T. Geneesk, 102, 1690.

Nomenclature for Human Immunoglobulins (1964). Bull. Wld Hlth Org., 30, 447.

Osserman, E. F. (1958). Radiology, 71, 157.

Putnam, F. W., Easley, C. W., Lynn, L. T., Ritchie, A. E., and Phelps, R. A. (1954). Arch. Biochem., 83, 115.

Ruffié, R., Bouissou, H., Fournié, A., Suc, J.M., and Putois, J. (1963). Rev. Rhum., 30, 348.

Short, I. A., and Smith, J. P. (1959). Scot. med. J., 4, 89.

Sirota, J. H., and Hamerman, D. J. (1954). Amer. J. Med., 16, 138.

Soothill, J. F. (1962). J. Lab. clin. Med., 58, 859.

Stevenson, G. T. (1962). J. clin. Invest. 41, 1190.

Stowers, J. M., and Dent, C. E. (1947). Quart. J. Med., 16, 275.

Takatsuki, K., and Osserman, E. F. (1964). J. Immunol., 92, 100.

Waldenström, J. (1944). Acta med. scand., 117, 216.

(1964). Ibid., 176, 345. 